\title{
STUDI LITERATUR: KAJIAN GEOTEKNIK DAERAH PERBATASAN SEBAGAI SALAH SATU FAKTOR DALAM PENGUATAN INFRASTRUKTUR DAERAH PERBATASAN DI KABUPATEN BELU, NUSA TENGGARA TIMUR
}

\author{
Undayani Cita Sari ${ }^{1}$ \\ Boby Rahman ${ }^{2}$ \\ Departemen Teknik Sipil, Universitas Diponegoro, Semarang ${ }^{1}$ \\ Program Studi Perencanaan Wilayah dan Kota, Universitas Islam Sultan Agung, Semarang ${ }^{2}$ \\ Penulis Korespondensi e-mail: undayanicita@live.undip.ac.id
}

\begin{abstract}
Although Indonesia is a maritime country with most of it is oceans, there are several regions in Indonesia bordering land with neighboring countries. There are Kalimantan with Malaysia, Papua with Papua New Guinea, and East Nusa Tenggara with Timor Leste. This border area can be admitted as a benchmark for development of country. This is because geographically the border area is far from the center of Government. Thus, if this area develops, the Government in general has succeeded in increasing development. Infrastructure development is one of the most prominent things in the border area. By great and eminent quality of infrastructure, the border area as a reflection of a country will become more clearly. However, as the basic concept of infrastructure construction, development in border areas also needs to consider the geotechnical characteristics of the region. Moreover, location of border areas is far and difficult to reach, so that it becomes an obstacle to do the development. Therefore, this paper reviews the geotechnical aspects based on literature studies in the Indonesian border area. The border location to be reviewed in this paper was in Timor Leste, Belu District. So that this paper is expected to be one of the contributions as reference regarding the situation in the border area. The geotechnical conditions of the border area reviewed in this paper were soil, rock and topography conditions, which can be used as a basic concept for infrastructure development.
\end{abstract}

Keywords: Belu districk, Border area, Infrastructure, Geotechnical

\begin{abstract}
ABSTRAK
Walaupun Indonesia sebagai negara maritime dengan sebagian besar berupa lautan, tetapi terdapat beberapa wilayah di Indonesia yang berbatasan darat dengan negara tetangga, yaitu di Pulau Kalimantan yang berbatasan dengan Malaysia, Papua berbatasan dengan Papua Nugini, dan Nusa Tenggara Timur dimana berbatasan dengan Timor Leste. Daerah perbatasan ini dapat dianggap sebagai tolak ukur pembangunan dari suatu negara. Hal ini dikarenakan bahwa secara geografis kawasan perbatasan jauh dari pusat Pemerintahan, maka apabila kondisi kawasan perbatasan maju, jika ditinjau dari pembangunannya, maka Pemerintah dapat dianggap secara umum telah berhasil meratakan pembangunan. Pembangunan infrastruktur adalah salah satu hal yang paling menonjol di daerah perbatasan. Dengan infrastruktur yang lengkap dan bermutu baik, maka kawasan perbatasan sebagai cerminan diri dari suatu negara akan terasa semakin jelas. Namun demikian, sebagaimana konsep dasar pembangunan infrastruktur yang ada, pembangunan di daerah perbatasan pun perlu memperhitungkan karakteristik geoteknik wilayah tersebut. Posisi daerah perbatasan yang umumnya jauh dan sukar dijangkau pun membuat pembangunan infrastruktur menemui kendalanya sendiri. Oleh karena itu, pada tulisan ini melakukan tinjauan terhadap aspek geoteknik berdasarkan studi literatur yang ada di daerah perbatasan Indonesia yang berbatasan dengan Timor Leste, yaitu Kabupaten Belu. Sehingga diharapkan dapat sebagai salah satu kontribusi dalam memberikan sumbangsih referensi mengenai keadaan di daerah perbatasan. Kondisi geoteknik daerah perbatasan yang ditinjau pada tulisan ini mencangkup kondisi tanah, batuan dan topografi, yang dapat digunakan sebagai konsep dasar dari pembangunan infrastruktur.

Kata Kunci: Kabupaten Belu, Daerah perbatasan, Infrastruktur, Geoteknik
\end{abstract}


Jurnal Planologi Vol. 16, No. 1, April 2019

Available : http://jurnal.unissula.ac.id/index.php/psa

\section{PENDAHULUAN}

Batas wilayah negara sangat penting untuk diperhatikan karena digunakan sebagai penanda teritori dari suatu negara. Hal ini agar tidak terjadi kesimpangsiuran kebijakan dan peraturan apabila pada suatu saat terjadi kejadian di wilayah tersebut. Berbagai macam variasi bentuk dari perbatasan suatu negara, dapat berupa gapura, tugu, sungai, laut, maupun pagar.

Berdasarkan Raharjo (2013), Indonesia adalah negara kepulauan yang memiliki 18.110 pulau dengan luas wilayah teritorial 3,1 juta $\mathrm{km}^{2}$ dan wilayah perairan 5,8 juta $\mathrm{km}^{2}$. Sementara itu, secara geografis, Indonesia diapit oleh dua benua, yaitu Asia dan Australia serta dua Samudra (Hindia dan Pasifik). Dengan kondisi geografis Indonesia yang sangat luas tersebut, maka wilayah-wilayah di perbatasan Indonesia sangat perlu diperhatikan.

Sebagai negara maritim, Indonesia memiliki luas lautan lebih besar dari pada luas daratan. Oleh karena itu batas wilayah lebih banyak berada di lautan dari pada di daratan. Namun demikian, batas wilayah di daratan perlu juga diperhatikan karena merupakan wilayah dimana masyarakat lebih sering berada. Hal ini dikarenakan masyarakat dengan mudah dapat menaiki kendaraaan atau berjalan kaki dari negara satu ke negara lain dengan melewati batas darat wilayah tersebut.

Negara Indonesia memiliki perbatasan darat Internasional dengan tiga negara tetangga yaitu Malaysia, Papua Nugini, dan Timor Leste. Sedangkan di laut, perairan Indonesia berbatasan dengan sepuluh negara tetangga yaitu India, Singapura, Malaysia, Thailand, Vietnam, Filipina, Palau, Australia, Timor Leste, dan Papua Nugini.

Perbatasan darat Indonesia dengan Malaysia, Timor Leste, dan Papua Nugini adalah sepanjang 3092,8 km (Raharjo, 2013). Bagian wilayah Indonesia yang berbatasan darat langsung dengan Malaysia adalah di bagian utara dimana terletak di Pulau Kalimantan. Sedangkan, Papua Nugini terletak di batas wilayah sebelah timur Indonesia. Timor Leste sendiri merupakan batas wilayah Indonesia yang terletak di bagian selatan.

Lebih lanjut, konsekuensi dari batas wilayah darat adalah adanya kawasan perbatasan. Kawasan perbatasan negara adalah wilayah dimana secara geografis memiliki batas secara langsung di darat dengan negara lain atau tidak langsung melalui laut lepas (Sudiar, 2015). Sedangkan menurut Undang-Undang No. 43 Tahun 2008 tentang Wilayah Negara, kawasan perbatasan adalah bagian dari wilayah negara yang terletak di sisi dalam sepanjang batas wilayah Indonesia dengan negara lain, dalam hal batas wilayah negara di darat, kawasan perbatasan berada di kecamatan. 
Jurnal Planologi Vol. 16, No. 1, April 2019

Saat ini, kawasan perbatasan berperan sebagai beranda suatu negara karena dapat menjadi cermin diri yang dapat dilihat langsung oleh masyarakat di negara tetangga. Selain itu, kawasan perbatasan juga dapat menjadi tolak ukur pembangunan. Hal ini dikarenakan secara geografis kawasan perbatasan jauh dari pusat Pemerintahan, maka apabila kondisi kawasan perbatasan maju, jika ditinjau dari pembangunannya, maka Pemerintah dapat dianggap secara umum telah berhasil meratakan pembangunan.

Undang-Undang Republik Indonesia Nomor 26 Tahun 2007 tentang Penataan Ruang dan Peraturan Pemerintah Republik Indonesia Nomor 26 Tahun 2008 tentang Rencana Tata Ruang Wilayah Nasional menyebutkan bahwa kawasan perbatasan digolongkan pada kawasan strategis, yang penataan ruangnya diprioritaskan dalam pelaksanaan pembangunan (Raharjo, 2013). Berdasarkan hal tersebut, salah satu hal yang paling menonjol di daerah perbatasan adalah pembangunan infrastruktur. Dengan infrastruktur yang lengkap dan bermutu baik, maka kawasan perbatasan sebagai cerminan diri dari suatu negara akan terasa semakin jelas. Manfaat yang dapat diperoleh dari pembangunan infrastruktur di daerah perbatasan bagi masyarakat adalah:

- Membantu masyarakat dengan adanya konstruksi sipil yang membantu pemenuhan kebutuhan hidup.

- Meningkatkan ekonomi masyarakat perbatasan. Hal ini dikarenakan dengan perkembangan infrastruktur yang semakin maju, kemudahan dalam berwirausaha akan meningkatkan perekonomian sehingga dapat berkembang dengan lebih pesat.

- Kemudahan dalam akses. Sebagai contoh adalah dengan adanya infrastruktur jalan raya, maka masyarakat akan dengan mudah berpindah dari suatu tempat ke tempat lain untuk menyelesaikan pekerjaan. Hal ini menguntungkan dimana masyarakat yang memiliki kepentingan mendesak tidak perlu menggunakan transportasi umum dimana sangat tergantung pada jadwal perjalanan, cuaca dan lain sebagainya.

Namun demikian, sebagaimana konsep dasar pembangunan infrastruktur yang ada, pembangunan di daerah perbatasan pun perlu memperhitungkan karakteristik geoteknik wilayah tersebut. Hal ini tidak lepas dari kondisi topografi dan struktur geologi yang melingkupi daerah perbatasan. Posisi daerah perbatasan yang umumnya jauh dan sukar dijangkau pun membuat pembangunan infrastruktur menemui kendalanya sendiri. Hal ini diperkuat dengan pernyataan Marwasta (2016) bahwa sebagian besar perbatasan di 
Indonesia yang berbatasan langsung dengan negara tetangga (melalui darat) terletak jauh di hutan dimana merupakan lokasi yang sulit dijangkau.

Oleh karena itu, pada tulisan ini meninjau sisi geoteknik berdasarkan studi literatur yang ada di daerah perbatasan Indonesia. Tinjauan pada kajian studi ini adalah di Kecamatan Belu dimana berbatasan dengan Timor Leste. Sehingga tulisan ini diharapkan dapat sebagai salah satu kontribusi dalam memberikan sumbangsih referensi mengenai keadaan di daerah perbatasan.

Kondisi geoteknik daerah perbatasan sendiri dapat mencangkup kondisi tanah, batuan, dan topografi, yang dapat digunakan sebagai dasar dari pembangunan infrastruktur. Pengetahuan mengenai kondisi geoteknik ini menjadi penting untuk diketahui karena dengannya dapat digunakan untuk menentukan apakah tanah di lokasi tersebut dapat langsung dilakukan pembangunannya atau memerlukan perbaikan tanah.

Perbaikan tanah atau soil improvement suatu wilayah ini bertujuan agar tanah sebagai pondasi dari suatu konstruksi dapat menahan beban yang ada di atasnya dan tidak terjadi keruntuhan. Selain itu dengan adanya pengetahuan mengenai kondisi geoteknik maka dapat diketahui pula apakah tanah atau batuan yang berada di wilayah tersebut digunakan sebagai quarry maupun borrow area sehingga dapat meminimalkan biaya konstruksi yang diperlukan dalam pembangunan.

\section{METODOLOGI}

Pada tulisan ini menggunakan metodologi kualitatif dengan teknik analisis literatur review. Marzali (2016) mengemukakan bahwa literatur review adalah penelusuran atau penelitian kepustakaan dengan membaca jurnal, buku, dan sumber lainnya yang berkaitan dengan topik penelitian yang ditinjau, untuk menghasilkan satu tulisan yang berhubungan dengan satu topik tertentu. Dengan menggunakan analisis literatur review ini maka dapat dianalisis kajian-kajian mengenai geoteknik, sehingga dapat diperoleh kesimpulan akhirnya.

Sebagai literatur, pada tulisan ini tidak hanya menggunakan buku, jurnal, maupun prosiding, tetapi juga berdasarkan peta. Hal ini dikarenakan dengan menggunakan peta dapat mengetahui lebih jelas penyebaran untuk beberapa karakteristik geoteknik seperti batuan dan tanah. Tulisan ini mengambil tinjauan di Kabupaten Belu, Nusa Tenggara Timur dimana salah satu Kabupaten di Nusa Tenggara Timur yang berbatasan langsung dengan Timor Leste. 
Jurnal Planologi Vol. 16, No. 1, April 2019

Available: http://jurnal.unissula.ac.id/index.php/psa

\section{HASIL DAN PEMBAHASAN}

Secara umum, karakteristik geoteknik daerah perbatasan di Indonesia memiliki dua keadaan yang perlu dipertimbangkan. Karakteristik tersebut adalah adanya tanah lunak dan keadaan geologi yang terkait batuan. Kedua hal tersebut dijelaskan pada Sub bab berikut.

\subsection{Kondisi Umum Tanah Lunak di Daerah Perbatasan Indonesia}

Berdasarkan Pedoman Kimpraswil No: Pt T-8-2002-B, tanah lunak merupakan tanah yang jika tidak dikenali dan diselidiki secara seksama dapat menyebabkan masalah ketidakstabilan dan penurunan jangka panjang yang tidak dapat ditolerir; tanah tersebut mempunyai kuat geser yang rendah dan kompresibilitas yang tinggi. Sehingga, dapat dikatakan bahwa tanah lunak adalah tanah yang biasanya memiliki karakteristik yang tidak baik sehingga berdampak pada daya dukung tanah dalam menerima beban di atasnya pun akan rendah. Yang termasuk dalam kategori tanah lunak adalah tanah lempung dan gambut.

Tanah lempung merupakan tanah kohesif dengan nilai kohesi atau daya ikat besar dan kuat geser kecil. Tanah lempung apabila memiliki nilai activity yang tinggi dan memiliki kandungan montmorillonite maka akan sangat berpotensial menjadi tanah ekspansif. Tanah ekspansif ini perlu diwaspadai karena kondisi tanahnya yang berubahubah, yaitu pada saat musim hujan atau terkena air akan mengembang tetapi pada saat kemarau atau kering dapat menyusut karena kehilangan air.

Karena kembang susut (swell shrinkage) faktor inilah maka dapat mempengaruhi struktur diatasnya. Kembang susut pada tanah dapat menyebabkan bangunan di atasnya mengalami penurunan bersama atau penurunan sebagian. Dampak dari hal ini adalah bangunan diatasnya dapat mengalami keruntuhan.

Sementara itu, tanah gambut merupakan tanah organik karena penyusun utamanya adalah dari sisa-sisa tumbuhan. Karakteristik dari tanah gambut ini adalah sebagai penyimpan air. Apabila terdapat hujan maka lahan gambut dapat membantu sebagai lokasi penyimpanan air di wilayah tersebut. Hal ini menyebabkan lahan gambut berfungsi juga sebagai tampungan yang berperan meminimalisir terjadinya banjir di suatu wilayah. Oleh karena itu, alih fungsi lahan gambut menjadi pemukiman atau infrastruktur lainnya sangat perlu diperhatikan.

Gambar 1 menunjukkan peta penyebaran tanah lunak di Indonesia. Dapat dilihat bahwa sebagian besar wilayah di Indonesia merupakan tanah lunak. Namun demikian 
terdapat juga endapan kwarter dimana termasuk juga endapan aluvial yang berbutir kasar (Pedoman Kimpraswil No: Pt T-8-2002-B). Pada umumnya sedimen Kwarter merupakan batugamping koral serta batugamping napalan (Gurniwa, 2002).

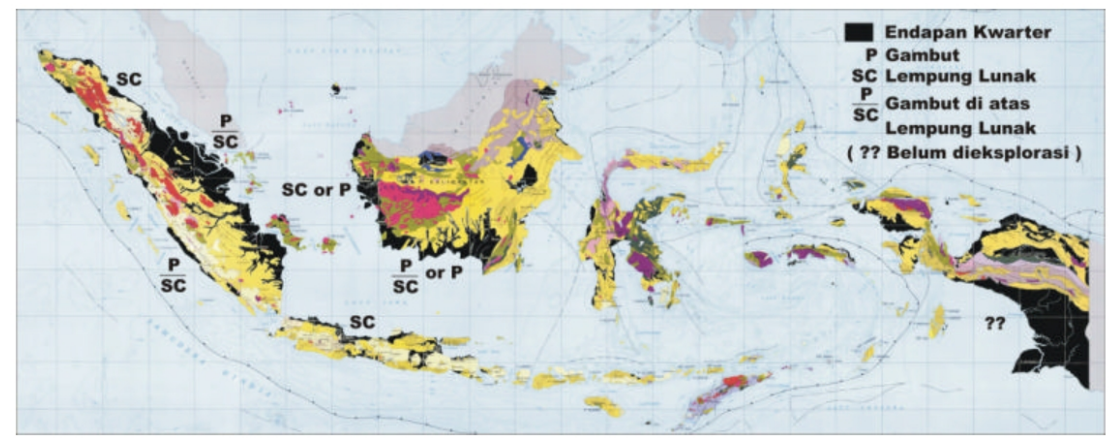

Gambar 1. Peta Lokasi Tanah Lunak di Indonesia Sumber : Pedoman Kimpraswil No: Pt T-8-2002-B

\subsection{Keadaan Umum Geologi di Daerah Perbatasan Indonesia}

Salah satu media yang dapat digunakan untuk mengetahui kondisi geologi suatu daerah adalah dengan menggunakan peta geologi. Hikmatullah et al. (2014) menjelaskan bahwa informasi geologi ini diperlukan untuk mengetahui formasi batuan dan menduga jenis batuan induk (litologi) yang mungkin dijumpai di lapangan, karena litologi sebagai salah satu komponen dalam menganalisis satuan lahan dan faktor pembentuk tanah. Peta geologi wilayah Indonesia dapat dilihat pada Gambar 2 (Pusat Penelitian dan Pengembangan Geologi, 1996).

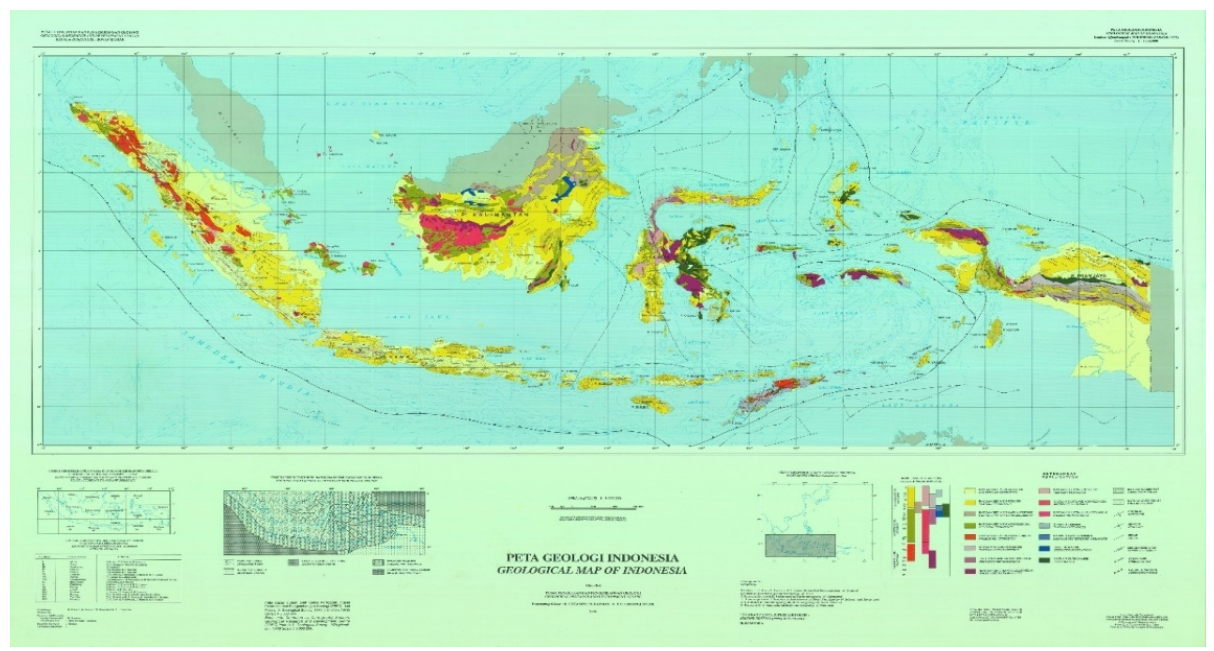

Gambar 2. Peta Geologi Indonesia

Sumber : Pusat Penelitian dan Pengembangan Geologi, 1996 
Jurnal Planologi Vol. 16, No. 1, April 2019

Berdasarkan peta geologi di Gambar 1, dapat dilihat bahwa untuk daerah perbatasan di utara atau di Pulau Kalimantan, struktur geologinya lebih banyak tersusun oleh batuan sedimen kapur-tersier, batuan sedimen mesozoikum, dan batuan sedimen tersier. Sementara itu untuk daerah perbatasan di wilayah sebelah Timur Indonesia atau yang berbatasan dengan Papua New Guinea, sebagian besar merupakan batuan sedimen tersier dan batuan sedimen kuarter. Lebih lanjut, pada wilayah Indonesia bagian selatan pada wilayah Nusa Tenggara Timur (Pulau Timor) lebih banyak tersusun bancuh tersier.

Batuan yang mengalami pelapukan dan erosi akan mengendap di suatu lokasi membentuk sedimentasi. Material sedimen tersebut kemudan akan terkompaksi, mengeras, dan mengalami litifikasi, sehingga terbentuklah batuan sedimen (Fitri et al., 2017). Dikarenakan berasal dari endapan sedimen maka karakteristik utama dari batuan sedimen ini adalah adanya bidang lapisan akibat proses sedimentasi tersebut. Berdasarkan Gurniwa (2002), batuan bancuh atau dapat disebut dengan melange merupakan bercampurnya berbagai macam batuan dengan berbagai ukuran dan komponen. Batuan ini dapat terdiri dari lempung bersisik, batupasir bermika, batu gamping, rijang, batuan ultrabasa, lava bantal, dan batuan malihan (Gurniwa, 2002).

\subsection{Daerah Perbatasan Kabupaten Belu}

Pada wilayah Indonesia bagian selatan, daerah yang berbatasan darat langsung dengan negara tetangga adalah di Pulau Nusa Tenggara Timur. Pada Pulau Nusa Tenggara Timur ini, Kabupaten yang berbatasan darat dengan Timor Leste adalah Kabupaten Belu dan Kabupaten Malaka. Namun demikian, bila dibandingkan dengan Kabupaten Malaka, Kabupaten Belu merupakan kabupaten yang kawasannya lebih besar terkait dengan batasnya langsung dengan Timor Leste. Posisi Kabupaten Belu dan Kabupaten Malaka dapat dilihat pada Gambar 3. 


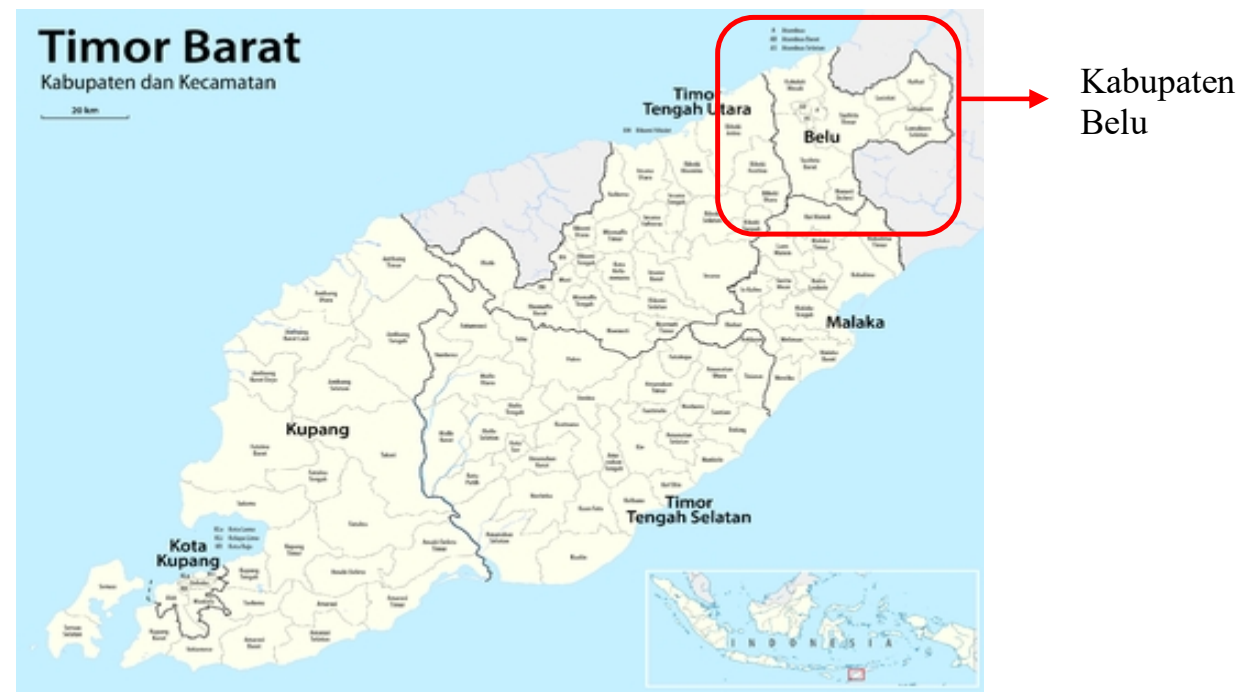

Gambar 3. Kabupaten Belu dan Kabupaten Malaka, Nusa Tenggara Timur Sumber : https://id.wikipedia.org/wiki/Timor_Barat

Kabupaten Belu memiliki luas wilayah administrasi 1.284,94 $\mathrm{km}^{2}$ dengan Atambua sebagai Ibu Kota Kabupaten (Badan Pusat Statistik Kabupaten Belu, 2018). Sementara itu, berdasarkan posisi geografisnya, Kabupaten Belu memiliki batas-batas sebagai berikut:

- Sebelah Utara

- Sebelah Selatan

- Sebelah Timur

- Sebelah Barat

\section{: Selat Ombai}

: Kabupaten Malaka

: Negara Timor Leste

: Kabupaten Timor Tengah Utara (TTU)

Berdasarkan https://belukab.go.id/ , topografi Kabupaten Belu bervariasi antara ketinggian 0 sampai dengan \pm 1500 meter di atas permukaan air laut. Ketinggian ini bervariasi di beberapa lokasi wilayah yang diuraikan sebagai berikut:

- Ketinggian 0 - 150 meter dpl : Sebagian kecil di bagian utara

- Ketinggian 200-500 meter dpl : Bagian tengah wilayah

Sementara itu pada wilayah pada bagian timur yang berbatasan langsung dengan Negara Timor Leste merupakan dataran tinggi (https://belukab.go.id/). Berdasarkan kemiringan lahan, wilayah Kabupaten Belu dapat dikelompokkan menjadi 5 (lima) kelas dengan masing-masing lokasi sebagai berikut:

1. Kemiringan lereng 0-8\%, yang merupakan dataran landai, terdapat di pesisir pantai Utara dan sekitar Kecamatan Kakuluk Mesak, Kecamatan Kota Atambua, Atambua Selatan dan Atambua Barat. 
Jurnal Planologi Vol. 16, No. 1, April 2019

2. Kemiringan lereng $8-15 \%$, merupakan daerah datar yang meliputi sebagian Kecamatan Tasifeto Barat.

3. Kemiringan lereng $15-25 \%$, yaitu daerah landai atau bergelombang yang meliputi daerah lembah yang terletak diantara pegunungan, terdapat di Kecamatan Raihat, Lasiolat, Lamaknen, Raimanuk dan bagian Timur Kecamatan Tasifeto Barat.

4. Kemiringan lereng $25-40 \%$, yaitu daerah yang bergelombang dan berbukit terdapat di di Kecamatan Tasifeto Timur, Nanaet Duabesi, Lamaknen, Lamaknen Selatan, Lasiolat kemudian di bagian tengah kabupaten terdapat di Kecamatan Raimanuk.

5. Kemiringan lereng di atas 40\%, terdapat di sebagian Kecamatan Nanaet Duabesi, Lasiolat dan sebagian besar di Kecamatan Lamaknen dan Lamaknen Selatan.

Sedangkan, untuk jenis tanah di Kabupaten Belu adalah sebagai berikut (https://belukab.go.id/):

- Tanah Alluvial dijumpai di Kecamatan Kota Atambua.

- Tanah campuran Alluvial dan Latosol dijumpai di Kecamatan Kakuluk Mesak, Lamaknen Selatan, Nanaet Dubesi dan Raimanuk.

- Tanah Latosol tersebar merata di wilayah Kabupaten Belu.

- Campuran tanah Meditera, Renzina dan Grumosol tersebar merata di wilayah Kabupaten Belu.

Berdasarkan data-data dari berbagai literatur yang telah diuraikan tersebut diatas, maka dapat dianalisis bahwa wilayah Kabupaten Belu, Nusa Tenggara Timur yang terletak di Pulau Timor sebagian besar merupakan wilayah batuan (Gambar 2). Hal ini juga dibuktikan dengan penelitian oleh Ramli (2005) dimana menyelidiki wilayah di Kabupaten Belu, Kabupaten Timor Tengah Selatan (TTS) dan Kabupaten Timor Tengah Utara (TTU). Hasil yang didapat adalah adanya batuan yang beragam dimana terdiri dari batuan volkanik, batuan beku, sedimen dan batuan malihan dari berbagai umur. Meskipun demikian, Kabupaten Belu diprediksi tetap memiliki potensi kecil terhadap adanya tanah lunak di beberapa lokasi.

Setelah mengetahui keadaan di Kabupaten Belu tersebut, maka dapat dianalisis dua kondisi yang ada, yaitu apabila terdapat tanah lunak dan batuan yang tersebar di daerah perbatasan tersebut. Kondisi ini tidak terbatas dengan salah satu kondisi yang terlibat, tetapi dapat juga terjadi kondisi dimana sebagai lapisan atas adalah tanah lunak dan pada bagian bawah adalah batuan. Hal ini sangat penting diketahui dalam rangka pembangunan 
Jurnal Planologi Vol. 16, No. 1, April 2019

infrastruktur, dikarenakan menunjukkan daya dukungnya dalam menahan beban konstruksi di atasnya.

Dikarenakan potensi terhadap tanah lunak kecil, maka dapat dianggap bahwa sebagian besar merupakan tanah keras. Tanah keras ini baik dalam rangka pembangunan dikarenakan biasanya memiliki daya dukung tanah yang besar. Daya dukung tanah ini dapat dihitung dengan terlebih dahulu melakukan pengujian sondir maupun boring. Namun, perlu dipertimbangkan kondisi apabila terdapat tanah lunak. Potensi terhadap adanya tanah lunak di Kabupaten Belu memang kecil, tetapi tetap ada. Oleh karena itu, tetap perlu dilakukan pengujian tanah pada wilayah yang akan dilakukan pembangunan.

Dengan daya dukung yang rendah, tanah lunak perlu ditingkatkan daya dukungnya dengan metode-metode soil improvement yang tepat sesuai kondisi lapangan. Sebagai contoh dengan penerapan geotekstil maupun geomembrane, pencampuran tanah dengan bahan kimia, dan lain sebagainya. Selain itu, apabila tanah lunak terletak di lereng, dimana topografi Kabupaten Belu merupakan perbukitan, perlu adanya retaining wall berupa dinding penahan tanah maupun turap.

Pada tanah lunak, perlu juga diketahui nilai activity-nya. Hal ini dikarenakan, apabila tanah lunak termasuk dalam kategori ekspansive soil maka diperlukan perlakuan khusus dilapangan. Sebagaimana dijelaskan sebelumnya bahwa tanah ekspansif dapat menyebabkan kerusakan struktur diatasnya. Sebagai contoh penanganan tanah ekspansif adalah dengan memberikan drainase yang baik ataupun treatment dengan geotekstil sehingga meminimalisir tanah berinteraksi dengan air yang menyebabkan terjadinya kembang susut.

Sementara itu, pada Kabupaten Belu sebagian besar tersusun dari tanah Alluvial dan Latosol. Tanah Alluvial ini merupakan tanah endapan. Kedua jenis tanah ini dapat dimanfaatkan sebagai tanah untuk pertanian maupun perkebunan. Namun demikian, perlu tinjauan lebih mendalam mengenai kekuatan dari tanah ini dengan pengujian sondir maupun boring.

Sementara itu, meskipun sebagian besar Kabupaten Belu tersusun dari batuan, dikarenakan batuan yang terbentuk dari berbagai umur dan mengetahui bahwa batuan sedimen terdiri dari lapisan-lapisan, sehingga tetap perlu diketahui kekuatan dari batuan. Sehingga, apabila batuan tersebut dianggap sebagai bedrock, maka akan dapat menopang struktur yang terletak di atasnya. Secara geologi, batuan yang baik dapat dilihat dari 
kualitasnya melalui Rock Mass Quality (RMQ). RMQ ini didapatkan dari nilai Rock Quality Design (RQD). Tabel 1 menunjukkan klasifikasi RMQ berdasarkan RQD.

Tabel 1. Klasifikasi RMQ Berdasarkan RQD

\begin{tabular}{cc}
\hline Nilai RQD (\%) & Rock Mass Quality (RMQ) \\
\hline$<25$ & Sangat buruk \\
\hline $25-50$ & Buruk \\
\hline $50-75$ & Sedang \\
\hline $75-90$ & Baik \\
\hline $90-100$ & Sangat baik \\
\hline
\end{tabular}

Sumber: MINTEC, 2016

Dapat dilihat pada Tabel 1, bahwa semakin besar nilai RQD maka semakin besar pula nilai RMQ yang menunjukkan kualitas batuan yang baik. Sementara itu, dari sisi sipil, kekuatan batuan dapat dilihat secara kuantitatif berdasarkan nilai Uniaxial Compressive Strength (UCS). Kekuatan batuan dibentuk oleh suatu ikatan adhesi antarbutir mineral atau tingkat sementasi pada batuan tersebut, serta kekerasan mineral yang membentuknya. Sehingga untuk tipe batuan sedimentasi, yang terdiri dari beberapa lapisan endapan sangat diperlukan adanya pengujian ini. Tabel 2 menunjukkan nilai UCS dari batuan.

Tabel 2 menunjukkan bahwa nilai UCS terkecil adalah 0,25 $\mathrm{MPa}$ atau setara dengan $250 \mathrm{~kg} / \mathrm{cm}^{2}$, dimana diestimasikan sebagai kekuatan batuan ekstrim lemah. Meskipun demikian, sebenarnya pada tanah dengan pengujian sondir, apabila mendapatkan nilai qc sebesar $250 \mathrm{~kg} / \mathrm{cm}^{2}$ sudah dianggap tanah keras, sehingga pengujian sondir dapat dihentikan. Oleh karena itu, dapat dikatakan bahwa apabila terdapat batuan dibawah tanah di Kabupaten Belu dengan kondisi UCS seperti di Tabel 2, maka dapat diasumsikan masih kuat menerima beban. Namun, perlu dipertimbangkan pula parameter kekakuan batuan (modulus Young dan angka Poisson) serta kuat gesernya. Selain itu juga perilaku batuan, apakah batuan apabila mendapat tekanan dari atas akan mudah hancur.

Tabel 2. Klasifikasi Kekuatan Batuan

\begin{tabular}{lclc}
\hline \multicolumn{1}{c}{$\begin{array}{c}\text { Tingkat Estimasi } \\
\text { Kekuatan }\end{array}$} & Kode & \multicolumn{1}{c}{ Deskripsi } & UCS (MPa) \\
\hline Ekstrim lemah & R1 & Dapat diidentifikasi dengan kuku & $0.25-1$ \\
\hline Sangat lemah & R2 & $\begin{array}{l}\text { Sulit dibentuk dengan kuku, dapat } \\
\text { dikupas mudah dengan pisau }\end{array}$ & $1-5$ \\
\hline Lemah & R3 & $\begin{array}{l}\text { Pisau memotong batuan namun sulit } \\
\text { untuk membentuk bagian triaksial }\end{array}$ & $5-25$ \\
\hline Hampir kuat & R4 & $\begin{array}{l}\text { Pukulan palu membagi batuan } \\
\text { menjadi ukuran 5 mm dalam sekali } \\
\text { pukulan }\end{array}$ & $25-50$ \\
\hline
\end{tabular}


Jurnal Planologi Vol. 16, No. 1, April 2019

\begin{tabular}{lllc}
\hline Kuat & R5 & $\begin{array}{l}\text { Hand-specimen hancur dengan sekali } \\
\text { pukulan palu geologi }\end{array}$ & $50-100$ \\
\hline Sangat kuat & R6 & $\begin{array}{l}\text { Membutuhkan pukulan berulang } \\
\text { untuk bisa memecahkan batuan } \\
\text { menjadi beberapa bagian }\end{array}$ & $100-250$ \\
\hline Ekstrim kuat & R7 & $\begin{array}{l}\text { Material hanya terkikis saja pada } \\
\text { pukulan palu geologi yang berulang, } \\
\text { berbunyi nyaring jika dipukul }\end{array}$ & $<250$ \\
\hline
\end{tabular}

Sumber : ACARP Project C22017 (2015) dalam MINTEC (2016)

Kelayakan batuan juga dapat ditinjau dari Rock Massa Rating System (RMRSystem), yang dapat digunakan untuk perencanaan terowongan, pondasi, lereng, dan lain sebagainya. Pada RMR-System menggunakan enam parameter untuk menilai kualitas massa batuan yaitu kuat tekan batuan (dengan UCS), RQD, kondisi air tanah, jarak bidang diskontinuitas, karakteristik diskontinuitas, dan orientasi diskontinuitas. Dengan mengetahui kekuatan dan kualitas setiap jenis batuan yang dihadapi maka dapat diketahui kelas dan arti massa batuan. Sehingga, dapat direncanakan perkuatan yang diperlukan pada kondisi wilayah yang ditinjau

\section{KESIMPULAN DAN SARAN}

\subsection{Kesimpulan}

Berdasarkan data dan analisis yang dilakukan, maka didapat kesimpulan bahwa wilayah Kabupaten Belu, Nusa Tenggara Timur sebagian besar berupa gunung dan bukit dan sedikit dataran. Tersebar batuan yang beragam dan dari berbagai umur. Meskipun demikian, Kabupaten Belu diprediksi tetap memiliki potensi kecil terhadap adanya tanah lunak di beberapa lokasi.

\subsection{Saran}

Meskipun telah diketahui mengenai geologi dan tanah dari Kabupaten Belu, Nusa Tenggara Timur, namun penyelidikan geoteknik dengan pengujian lapangan (sondir dan boring) dan laboratorium (index dan engineering properties) diperlukan sebagai data primer dalam perencanaan pembangunan struktur. Hal ini dikarenakan data secara kuantitatif sangat diperlukan dalam perhitungan perencanaan. Selain itu, sebagian besar wilayah tersusun dari batuan sedimen. sehingga diperlukan penyelidikan pada batuan mengenai mekanika batuan dan apakah terdapat crack ataupun fissure yang dapat mempengaruhi kekuatan batuan tersebut dalam menahan beban terutama pada daerah dengan slope curam. Perlu dipertimbangkan pula properties batuan tersebut untuk mendukung analisis geoteknik. 
Jurnal Planologi Vol. 16, No. 1, April 2019

Available : http://jurnal.unissula.ac.id/index.php/psa

\section{DAFTAR PUSTAKA}

Badan Pusat Statistik Kabupaten Belu. (2018). Kabupaten Belu dalam Angka 2018. Badan Pusat Statistik Kabupaten Belu.

Fitri, D.B., Hidayat, B., Subandrio, A.S. (2017). Klasifikasi Jenis Batuan Sedimen Berdasarkan Tekstur dengan Metode Gray Level Co-Occurrence Matrix dan K-NN. e-Proceeding of Engineering, 4 (2), 1638-1645.

Gurniwa, A. (2002). Penyelidikan Geokimia Regional Sistematik Lembar Kupang, Kabupaten Kupang Provinsi Nusatenggara Timur. Kolokium Direktorat Inventarisasi Sumber Daya Mineral (DIM) TA. 2002, 24-1 - 24-12.

Hikmatullah, Suparto, C. Tafakresnanto, Sukarman, Suratman dan K. Nugroho. (2014). Petunjuk Teknis Survei dan Pemetaan Sumberdaya Tanah Tingkat Semi Detail Skala 1:50.000. Balai Besar Penelitian dan Pengembangan Pertanian, Badan Penelitian dan Pengembangan Pertanian, Bogor.

Marwasta, D. (2016). Pendampingan Pengelolaan Wilayah Perbatasan di Indonesia: Lesson Learned dari KKN-PPM UGM di Kawasan Perbatasan. Jurnal Pengabdian kepada Masyarakat (Indonesian Journal of Community Engagement), 1(2), 204-216.

Marzali, A. (2016). Menulis Kajian Literatur. Jurnal Etnosia 01 (02), 27-36.

MINTEC. (2016). Buku Saku Eksplorasi Batu Bara. PT. Mintec Abadi.

Pedoman Kimpraswil No: Pt T-8-2002-B. Panduan Geoteknik 1, Proses Pembentukan dan Sifat-sifat Dasar Tanah Lunak. Departemen Permukiman dan Prasarana Wilayah

Pusat Penelitian dan Pengembangan Geologi. (1996). Peta Geologi Indonesia.

Raharjo, S. N. I. (2013). Kebijakan Pengelolaan Kawasan Perbatasan DaratIndonesiaMalaysia (studi evaluatif di Kecamatan Entikong). Widyariset, 16(1), 73-80.

Ramli, Y.Z. (2005). Penyelidikan Geokimia Regional Sistematik Lembar Atambua Provinsi Nusa Tenggara Timur. Kolokium Hasil Lapangan - DIM, PP 16-1 - 16-13.

Sudiar, S. (2017). Pembangunan Wilayah Perbatasan Negara: Gambaran Tentang Strategi Pengelolaan Kawasan Perbatasan Darat Di Provinsi Kalimantan Utara. Jurnal Administrative Reform (JAR), 3(4), 489-500

Undang-Undang No. 43 Tahun 2008 tentang Wilayah Negara

https://belukab.go.id/ diakses pada 22 Maret 2019.

https://id.wikipedia.org/wiki/Timor_Barat diakses pada 02 April 2019. 